\title{
Original Article \\ Critique by design: Tackling urban renewal in the design studio
}

\author{
Bülent Batuman* and Deniz Altay Baykan
}

Department of Urban Design and Landscape Architecture, Bilkent University, Ankara, 06800, Turkey. E-mails: bbatuman@gmail.com; altay@bilkent.edu.tr

*Corresponding author.

\begin{abstract}
The dominant mode of urbanization in our contemporary world is marked by large scale urban renewal projects, which are deployed with little or no consideration given to the social predicaments. The urban design studio can serve as a domain in which critical reflections on urban issues can be incorporated into design works. In this article, we propose a methodology of 'critique by design', which does not seek to arrive at scientific knowledge but rather involves the development of urban design proposals critically engaging with the urban issues they address through conceptual approaches. We discuss our methodology through the case of an experimental studio work conducted in Ankara, Turkey at Bilkent University, Department of Urban Design and Landscape Architecture in 2011.
\end{abstract}

URBAN DESIGN International (2014) 19, 199-214. doi:10.1057/udi.2013.40; published online 8 January 2014

Keywords: urban design; built environment; design research; design education; critique by design

Today, the implementation of large scale urban renewal projects is still a globally valid strategy of urbanization especially in the developing world, despite the negative effects of the economic recession. While the political economy and the social costs of this strategy have been widely discussed (and harshly criticized) for more than two decades, the practice of urban design seems to have evaded such criticisms. This is not to say that the social dimensions of - or the lack of addressing these aspects by - urban design have not been questioned. On the contrary, scholars have scrutinized the relation between urban design and the social processes affected by it (Cuthbert, 2006; Inam, 2011). It has been proposed to search for links between the two, providing mutual improvement between urban design and urban life (Ellin, 2006; Sargin and Savaş, 2012). Nevertheless, the specific historical conditions of our contemporary world require directly addressing the issue of urban renewal while discussing the practice of urban design, since the former is only possible through the operational use of the latter. As it has been widely discussed, the urban regime shaped under the global influence of neoliberal economy is closely related to the use of urban renewal as a tool of capital accumulation (Harvey, 1989; Brenner and Theodore, 2002; Hackworth, 2007). Within this context, a discussion on urban design has to address the contemporary conditions of urbanization.

One way of addressing these conditions is to incorporate knowledge production into the very process of urban design; and the realm of education provides suitable grounds for this enterprise. The role of research within its relation with design practice is becoming a crucial component of the disciplines of the built environment (Biggs and Büchler, 2008; Biggs and Karlsson, 2011). The design studio is gradually becoming a space in which the students are not only trained via tackling sample problems but are also required to critically reflect on the issues they address through their works. Yet, urban design education often falls short in developing systematic approaches to bring together research and work-based learning (Savage, 2005; Çalışkan, 2012). In this study, we propose a strategy of 'critique by design', which does not claim to extract scientific knowledge in 
the traditional sense of research. Rather, this strategy involves the development of urban design proposals critically engaging with the urban issues they address through conceptual approaches.

Here, it is necessary to briefly explain what is meant by critique by design. Typically, the term 'critique' implies a formal negativity; a total rejection of the object of critique. In this regard, a critique of urban renewal inevitably recalls an absolute negation of the process. Obviously, it does not make sense to abandon urban renewal as a generic operation of urban transformation and speak of urban design. At this point, it is useful to refer to the distinction between 'transcendental critique' and 'immanent critique' as proposed by Adorno (1983) (see also, Antonio, 1981). Accordingly, whereas transcendental critique is a critique from outside, immanent critique is critique from within. Whereas the former operates on a general and abstract level, the latter engages with the process it critiques in a heterodox way. In this respect, critique by design seeks to arrive at an immanent critique of urban renewal within and through the design process.

\section{Background}

This article discusses an experimental design studio, which employed the methodology of 'critique by design'. The studio was conducted in Ankara, Turkey at Bilkent University, Department of Urban Design and Landscape Architecture in 2011. The department's curriculum contains technical courses in landscape architecture (plant material, planting design, construction and so on) as well as urban design studios, and the students graduate with the professional title of landscape architect. The urban design studios, following the first year basic design studio, are organized in three 'vertical' studios including students from second, third and fourth year. These three vertical studios, which each student has to attend twice throughout their education, are defined with the strategic emphasis they put within the design process. Whereas the 'Context and Design' Studio prioritizes the inputs of the urban context, the 'Form and Design' Studio explores formal approaches to urban design. The 'Concept and Design' Studio, where the project under discussion was pursued, deploys design strategies based on conceptual investigations rather than contextual data. Each semester our studio brings into question a particular concept that would become the major instrument for the students to investigate, analyze and propose design schemes for the urban problem at hand. The intention is to expand the intellectual terrain within which the students work by freeing them from the constraints of the context only to address them in a later phase of the design process. The studio included 14 second year and 11 third year students together with two instructors in the semester under discussion.

The studio was designed in order to address the current conditions of the city of Ankara, the capital of Turkey, where numerous urban renewal projects are under way at present. Ankara was declared the capital in 1923 and the city experienced continuous growth afterwards (Tankut, 1994; Cengizkan, 2004). While its growth was relatively controlled until the Second World War, the postwar era witnessed massive rural-to-urban migration and the emergence of squatter districts around the city (Keleş and Danielson, 1985; Öncü, 1988; Şenyapill, 2004). Hence, the majority of the ongoing renewal projects are concerned with the regeneration of these areas (Güzey, 2009). The current approach to urban renewal in Turkey is characterized by the immense powers vested in the municipalities and the lack of participation in the decision-making processes (Ünsal and Kuyucu, 2010; Batuman, 2013). While the squatters are forced to leave their environments, the gentrification of these areas is advertised by elegant housing projects. Within this context, the instrumentalization of urban design becomes an ethical issue to be addressed within urban design education.

In terms of urban morphology, the recent trend in urban renewal in Turkish cities results in the reproduction of the rigid patterns of conventional blocks and lots with higher densities. Once cleared of slums, the old squatter neighborhoods are treated as vacant areas to be filled with buildings and become denser than ever. Departing from this point, this semester's project was defined as redesigning an urban valley that was cleared of slums in the early 1990s, and the semester's concept was designated as VOID.

\section{Methodology}

The 'critique by design' methodology we have deployed in the studio comprised different stages as illustrated in Table 1. The incorporation of this methodology into the studio process is also presented with the diagram in Figure 1. Accordingly, the first stage included exercises aiming to put the 
concept of void to scrutiny in order to dig into the multitude of meanings and connotations it embodied and to use it later as a means to develop design strategies. The intention of the studio instructors in this choice was to force students to face the tension between the (positive) implications of building/designing/developing and the (negative) connotations of the term. In the second stage, the students visited the site of another urban renewal project, where the squatters have resisted - and continue to resist - evacuation. This experience, which we defined as the drift à la Situationsts, allowed them to not only observe the social consequences of urban renewal but also further reflect on the concept of void as a social signifier as well as a physical one. Afterwards, the students were asked to interpret the drift within a sculpture workshop. Whereas the drift linked urban design to social space through bodily experience, the workshop aimed at translating the critical experience into design work. The third stage, 'Object Design', was a small exercise toward further developing the products of the sculpture workshop into architectural objects, which would be a part of the following stage of park design.

As mentioned above, the Concept and Design Studio aims at providing grounds to discuss the issue at hand through a conceptual approach that minimizes the role of the context. Therefore, at the fourth stage, the students were not given the actual site but were required to work on an imaginary terrain they would design. This was the beginning of the physical design process, where the students designed urban parks, using their object designs as point of departure. In the fifth and final stage, they were informed about the actual site and were asked to rework their proposals, this time to fit the requirements of the context.

Below, we will discuss the critique by design methodology following the sequences of the studio. After the analysis of sample proposals illustrating the strategic approaches that were developed in the studio, the article will arrive at an assessment of the outcomes of the studio in terms of our methodology. In our assessment, we will relate the common points emphasized in the student projects to the debates in landscape urbanism. Although landscape urbanism was not referred to in the studio, the shared approach of the students prioritizing landscape against building blocks as a critical design strategy matches with landscape urbanism's proposal to replace architecture with landscape as the basis of urban development. 


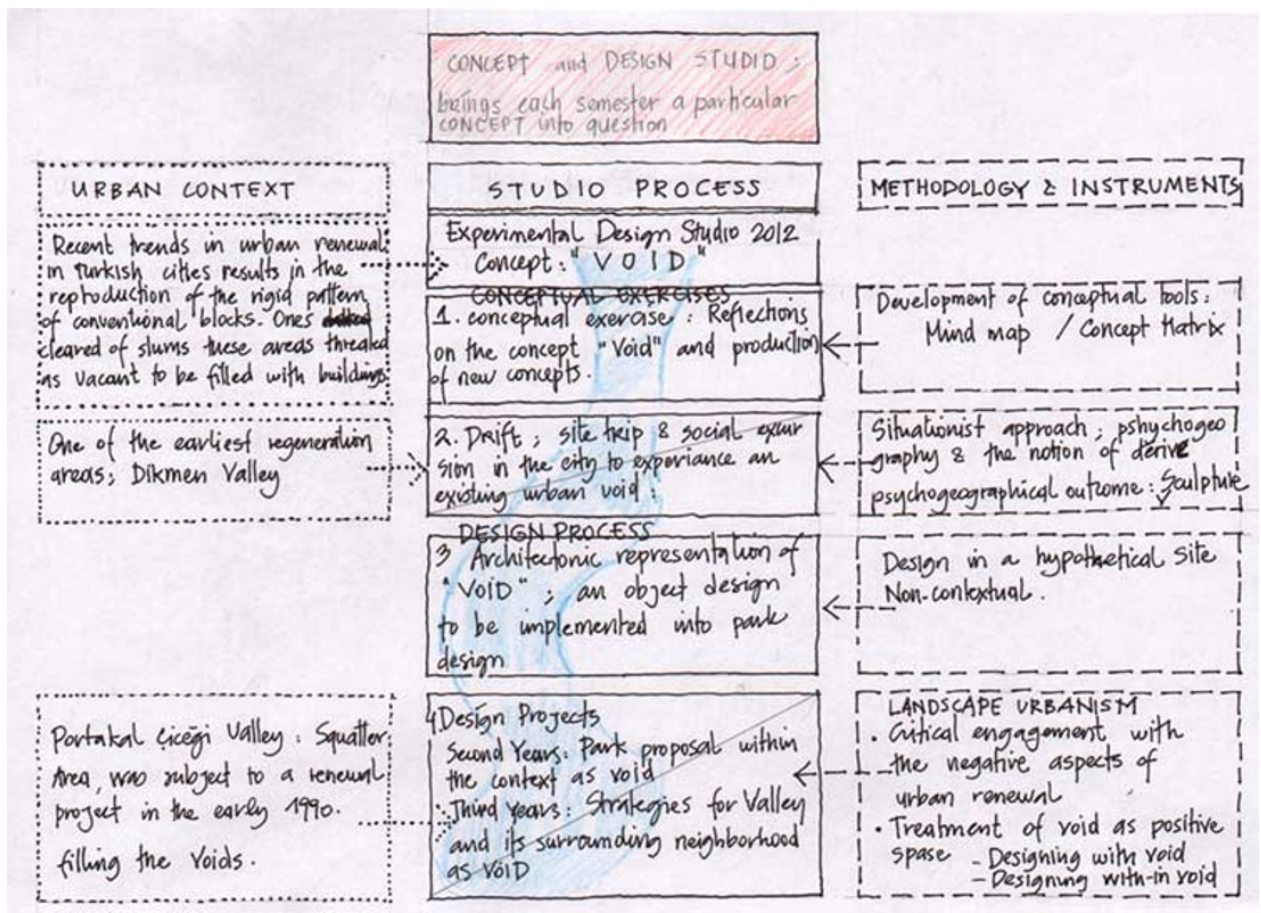

Figure 1: Diagram showing the studio process.

An important source we will use to assess the objectives of critique by design methodology is the results of a survey we have subsequently conducted with the students that participated in the studio. The students' responses to the survey questions allow us to consider the extent to which the studio objectives were achieved. The survey was not realized as a part of the studio process. It was conducted 1 year later, in order to have the students reflect on their experience and its influence on their way of thinking regarding urban design. As a result of the time lag, the students did not respond with their immediate reactions to the educational process, but rather contemplated on how the studio experience affected their approach to urban design and urban renewal. The survey included questions regarding three themes: the experience of the drift and its relation with the actual project site; the concept of void as a design tool; and the impact of the studio on the students' thinking on urban renewal.

\section{The Concept}

The choice of the concept of void relied first of all on the potentials of this concept in terms of critique by design methodology. The speculative logic of contemporary urbanism prioritizes the increase of building density in the old squatter areas. Hence, the gentrification of urban areas leads to the change of not only the user profiles but also the physical patterns of urban texture. In this respect, the concept of void is a productive tool for both critiquing the current mode of urban renewal and developing alternative design strategies. The constant promotion of verticality and the treatment of old residential districts as voids to be filled could be countered by the deployment of void as positive space; that is, horizontal surfaces as urban spaces. To strengthen this approach, the design problem for the studio process was defined as the organization of an open space in the form of an urban park. Afterwards, the urban park was used as a generator to develop landscape strategies toward regeneration of an area. By prioritizing landscape, it was intended to arrive at proposals that would avoid density and gentrification, and treat the site as an urban void to be used as public space.

The concept of void has been used in several architectural and urban design projects. For instance, Libeskind has used the concept in his Jewish Museum in Berlin (1992-1999). In his project, Libeskind created an empty axis along the famous zigzag-shaped building, making this void the backbone of his design. His intention was to use the void as a means to represent the absence of Jews in Berlin (Libeskind, 1999). Similarly, Michael 
Table 2: Conceptual work: The concepts derived from VOID

\begin{tabular}{llccl}
\hline Phenomenological & Spatial & Architectonic & Textual & Emotional \\
\hline Death & Hollow & Gap & Line space & Serenity \\
Birth & Hole & Transparency & Crossword puzzle & Silence \\
Silence & Pit & Empty & Idle talk & Pessimist \\
Pessimism & Cavity & To void & Empty talk & Timelessness \\
Time & Trench & Suspense & Hollow words & Melancholy \\
Avoidance & Fosse & Potential & Rest (music) & Avoidance \\
Peace & Stairwell & Echo & Rhythm & Peace \\
Loneliness & Shaft & Saturate & A-void & Loneliness \\
Desertedness & Echo & - & - & Fear \\
Lack & Cliff & - & - & Despair \\
Absence & Limit & - & - & Loss \\
Potential & Island & - & - & Indifferent \\
Loss & Gulf & - & - & Distress \\
Canyon & Canyon & - & - & Curiosity \\
Abyss & Abyss & - & - & Uncertainty \\
& Pore & - & Anxiety \\
& Fissure & - & Insecurity \\
\hline
\end{tabular}

Arad and Peter Walker's 'Reflecting Absence', their proposal for the World Trade Center Memorial (that is under construction) proposed two pools with cascading waterfalls located within the footprints of the twin towers of the WTC. For the designers, the two large voids among a field of trees are open and visible reminders of absence (Arad, 2009). As illustrated by these examples, void is utilized to represent traumatic events demanding the questioning of the very notion of representation and to give form to absence in order to resist the naturalization of loss. In addition to these examples, there are also architects and urban designers interested in searching for the potentials of existing urban voids as spaces of possibility and expectance (see for instance, SolaMorales Rubio, 1995; Bru, 2001). In such cases, the void is not an entity created to negate the existing urban realm but almost an organic element contained within it. The void, in this respect, can be dealt with in terms of its geographical (topographical fissures interrupting the urban texture), functional (vacant spaces ceased to be used) or phenomenological (the meanings stemming from context or history attached to it) characteristics (Rojas, 2009; Hall, 2010).

As the first step of the studio, the students were asked to reflect on the concept void and to derive new concepts utilizing the method of mind-map. The mind-map allows the students to explore distinct meanings embodied within the particular concept within a two-dimensional structure and allows them to establish relations between the newly arrived concepts (Buzan and Buzan, 2006).
As the students came up with numerous new concepts derived from void, we rearranged them within a table that groups the main approaches to the concept (Table 2). Whereas some of the concepts derived from void were literal types of voids, some of them explored the relational qualities of void, that is, human experiences, feelings and emotions in relation to it. The concepts charted by the students can be categorized under five headings: phenomenological, spatial, architectonic, textual and emotional. Although it is possible to propose other categories, our classification refers to the approaches within the studio. Here, phenomenological void is defined with concepts such as lack, absence, loss, desertedness and refers to the individual's psychological and affectual experience in space (Bachelard, 1964). Although spatial void includes both geographical (pit, cavity and hole) and human-made (shaft) voids, there are also geographical formations that can be considered as both spatial and phenomenological voids (canyon and abyss). The architectonic voids refer to the behavior of empty space under certain physical conditions (transparency and echo). Textual voids were explored by the students to reveal the structural gaps intrinsic to the use of language and its representational systems (rest, rhythm, line spacing and so on). Finally, a set of feelings and emotions triggered by void were put forward, which we listed under the category of emotional voids. It has to be noted that not all of these categories were addressed by the design projects in the following stages of the studio. Nevertheless, they represent the vast cognitive terrain within 


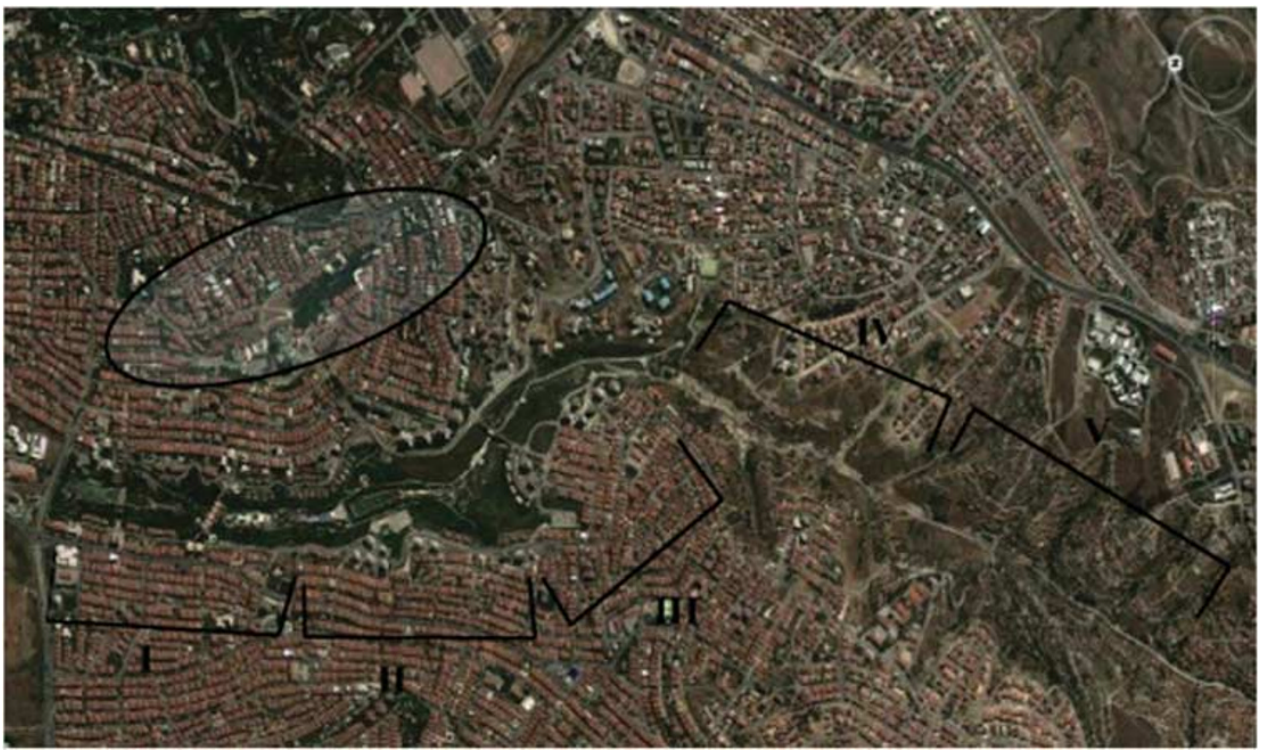

Figure 2: Dikmen Valley and the stages of the regeneration project. The area marked with the ellipse is the Portakal Çiçeği Valley. Source: Google Earth (Image (C) 2012 GeoEye).

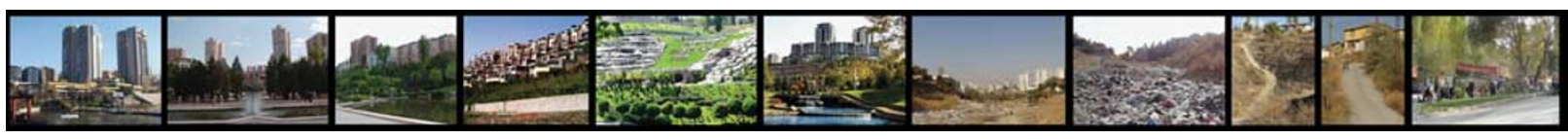

Figure 3: Panorama of Dikmen Valley showing the changing physical and social environment.

which the students tackled the concept of void in relation to urban design.

\section{The Drift}

Following this conceptual exercise, the students were invited to an excursion in the city to experience an existing urban void, which embodies physical and social dimensions of the concept simultaneously. It was intended to link urban design to social space by making the bodily experience in the city a component of the critical design process. In tune with the Situationists' concept of pshychogeography and their notion of dérive, the aim of the drift was to turn the practice of walking in the city into social critique; an inventive strategy to experience unforeseen and unpredictable encounters and lead the walkers to a new awareness of the urban environment (Debord, 2009a [1955]; Debord, 2009b [1956]). The site chosen for the drift was Dikmen Valley, one of the earliest regeneration sites, which runs $13 \mathrm{~km}$, and is actually very close to the actual project site of Portakal Çiçeği Valley (Figure 2). Dikmen Valley was proposed to be redeveloped in five phases and the first two were finished peacefully in the 1990s. The third phase, however, witnessed a drastic increase in building heights as well as floor areas of housing units and this significantly changed user demographics in the area. Meanwhile, the squatters in the fourth and fifth phase areas were forced to sign individual contracts on very disadvantageous terms. The squatters began organizing in response and established a 'Right to Shelter Bureau' to resist evacuation in 2006. Since then, the municipality has attempted to evacuate the squatters by force several times and the tension prevails.

The Valley currently provides a significant repertoire of distinct housing types, all of which can be observed in sequence through a walk along the Valley (Figure 3). The earliest housing blocks in the first phase are still inhabited by the squatters and exist side by side with the upper class houses built to compensate them. The park in the middle of these blocks is a public space used even by people coming from different parts of the city. Yet, as further one walks, the Valley gradually turns into a semi-gated community, where significant portions of the green areas are left to the private use of expensive housing complexes. After these well-designed buildings and elegant landscapes, one suddenly meets with concrete barriers signaling the limits of the completed project site. After 
the barriers lay a no-man's land with the debris of evacuated slums of the fourth phase, which are reoccupied by unsheltered people living on garbage collection. The contrast between the lavish landscape and the piles of recyclable garbage only a few hundred meters away from each other is striking. And after this vacant area, there are the traditional houses of the squatters who have been living in the Valley for more than three decades. The squatters are currently denied municipal services and have to resolve their needs communally. The students were welcomed by the squatters and were given a brief conference on their living conditions.

The survey responses illustrate the students' perception of the drift as a social encounter. One of the students put it as such: 'My first observation was [the site's] spatial quality as a valley. However, the deeper [sic] we went, I felt that this was a different type of void. It was [characterized by] disregard to the people living there ... and the [response of] pretending they did not exist'. Another one emphasized that the drift allowed them to observe the Valley as a social void, which meant the suppression of the existence of the squatters and the general ignorance regarding their hardships. The crucial point here is the students' frequent use of the term 'social void' in their responses, which represents their recollection of the drift as a social encounter. Moreover, a number of the students described their observations with particular attention to the spatial qualities of the different sections of the Valley. They defined the regenerated areas as 'alienated' from the 'actual nature of the valley' and interpreted the social gap between the inhabitants of the different sections in terms of environmental qualities. Accordingly, the designed spaces of the earlier stages were negatively evaluated as 'alien' and 'artificial', whereas, the prevailing squatter settlement was seen as 'genuine' and 'conforming to both the social organization of squatters and the physical characteristics of the valley'. The representation of social tension with reference to design quality is quite subjective; the regenerated areas are not necessarily bad designed. This representation should be understood as an intuitive response to the ethical dilemma faced by the students as designers.

Although the social encounter constituted an important component of the students' experience in the drift, they also perceived the Valley as a physical environment and experienced it with their senses. As one student put it, the drift triggered curiosity for their part and as a result their 'senses were heightened' throughout the drift. The students felt that the Valley was 'isolated' from the city and created a sense of 'abandonment'. The feeling of desertedness despite the sequential change of landscape was interpreted as the result of a negative enclosure created by the morphology of the Valley, which triggered 'anxiety'.

As the student responses demonstrate, the drift was successful in making students develop a sensual-experiential critique of urban renewal. Yet, the crucial point of critique by design methodology is translating critical insight into creative design work. For this, we devised a sculpture workshop, where the students were asked to represent their experience. The workshop was aimed at extracting the psychogeographical outcomes of the drift; in other words, interpreting social critique into design work. It took place the next day at the same place, in the courtyard of the 'Right to Shelter Bureau'. The students working in groups were provided with clay to work with, although they were unfamiliar with the material. Nevertheless, the workshop allowed the students to represent their experience of the Valley as void: a geographical void that is always felt with the cool breeze and the shade at the Valley bottom; a social void, with voided (and reoccupied) sections, sections intended to be evacuated, and sections refilled after being emptied. Hence, Dikmen Valley allowed the students to develop their own critique not through learned knowledge but through their experience in space using the concept of void. At the end of the drift, they were aware of a number of issues: the relation of a morphological void with a dense urban texture; the social dimensions of designing physical spaces; and the conflict between urban design and its instrumentalization for gentrification.

The products of the workshop were satisfying in their inspiration; the survey responses also support this impression. Almost all of the participants pointed out that the sculpture workshop had been very effective in obtaining products juxtaposing their observations and perceptions. In the students' words, the workshop allowed them 'to express both their feelings and thoughts'. One group represented the Valley as 'the hand of nature', an open hand with a crack stretching across the palm (Figure 4). Here, the gesture of the hand fits with the location of the Valley sloping down toward the city center. Hence, the counter expansion of the city into the Valley and toward the last group of squatters takes the form of a crack signaling catastrophe. Another group titled their work 


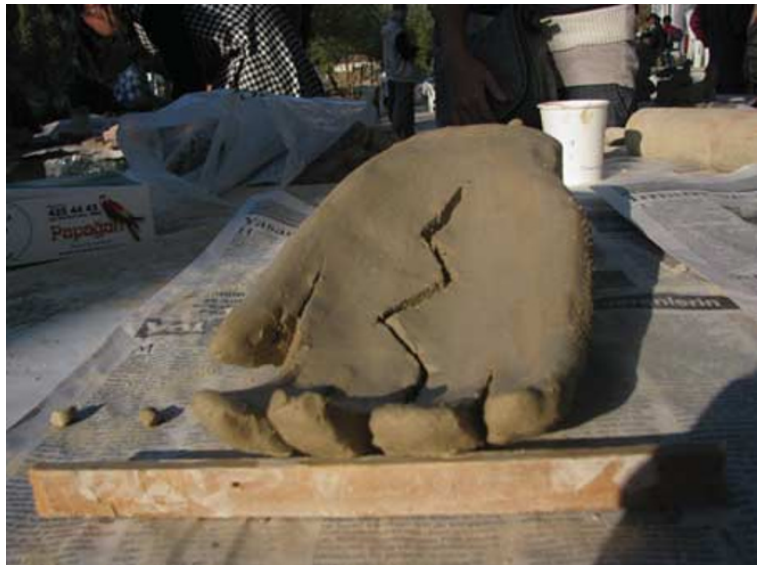

Figure 4: Sculpture workshop after the drift along Dikmen Valley: 'The Hand of Nature'. (Büşra Dok, Tuğçe Norman, Handan Çörekçi).

'cage', playing into the multiple meanings of the word. As the form itself recalls a rib cage, it refers to the geomorphological function of the Valley as a wind tunnel clearing the city's air. On the other hand, the elements of the cage are derived from the visual experience at the Valley bottom, with the high-rise buildings towering over the walker. Hence, the Valley is also a cage imprisoning the individual once it is deepened with the buildings lined alongside.

The psychogeographical experience of the drift is a practical application of immanent critique toward urban renewal. The walkers literally took place inside the object of their scrutiny and observed the very process in physical and social terms. They inhabited portions of the Valley that demonstrated the before and after conditions of renewal as well as the destroyed sections lying in between the two. That is, as the survey responses we have quoted above illustrate, the drift led the students to observe and experience the dialectics of creative destruction, which is characteristic of urban renewal (Harvey, 2003, pp. 16-18).

\section{The Design Process}

After the drift, the students returned to the studio and at the third stage of the process (Object Design) they were asked to provide an architectonic representation of void in the form of an object to be implemented within their park designs. The intention of this exercise was to channel the inspirational work of the sculpture workshop into park design. The object design was the first step of the physical design process. At the fourth stage
(Site Design I), the problem was defined as designing an urban park to cover an area of $40000 \mathrm{~m}^{2}$. The park was to be designed in a decontextual site, one to be also created by the students with its topographical and environmental conditions. Whereas the second year students were responsible for only park design, the third year students were also required to create an urban environment within which their design schemes would be implemented.

After a 3-week period that culminated in a preliminary jury, the students were informed that the actual site they would work was Portakal Çiçeği Valley and were asked to rework their proposals accordingly at the fifth stage (Site Design II). Portakal Çiçeği Valley is located 400 $\mathrm{m}$ to the east of Dikmen Valley and runs parallel to it, although it is much shorter (approximately $1 \mathrm{~km}$ ). The Valley was also a squatter area and was subject to a renewal project in the early 1990s. ${ }^{1}$ The most significant difference between the renewal projects implemented in these two areas was the relocation of the squatter population in Portakal Çiçeği Valley $20 \mathrm{~km}$ away. Whereas a few high-rise blocks for high-income groups and a shopping mall were constructed, the rest of the Valley was designed as green space. Currently, the southern half of the Valley, which is topographically higher, is a park and the rest is still under construction (Figure 5).

Within this area, the second year students were required to rework their park proposals and implement it to the southern half of the site (the size of which was approximately equal to their imaginary site). For these students, the major challenges were the topography of the Valley and the integration of the park to the surrounding neighborhood. The third year students, on the other hand, were asked to develop strategies for a larger area covering the Valley and its immediate surroundings. Here, the intention was to force the students to expand their design approaches derived from the concept of void into an urban development strategy generated by the use of landscape. Before discussing the outcomes, it is necessary to briefly discuss the produced design projects. As it was mentioned, although a vast array of new concepts was derived from void in the initial stage of the studio, not all of these categories were addressed in the design proposals. Therefore, below, we will present and discuss sample projects under a new grouping with the categories of physical, functional and phenomenological voids. 


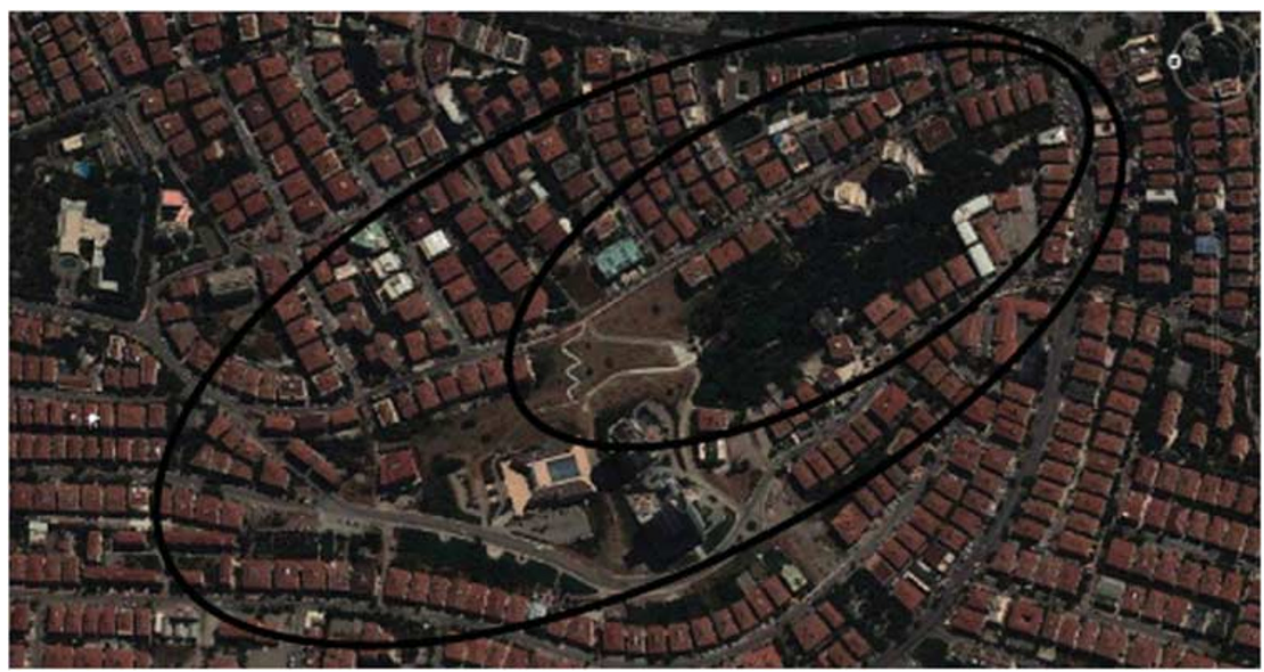

Figure 5: Portakal Çiçeği Valley. The second year students were responsible for designing the green area within the smaller ellipse and the third year students tackled with the whole Valley.

Source: Google Earth (Image @ 2012 GeoEye).

\section{Physical voids}

Most of the second year students approached the concept with its physical potentials and searched for ways to create three-dimensional voids that would become the components of park design. Departing from concepts such as hole, pit and cavity, these projects had to be thoroughly reworked in order to be applicable to the Valley. Although the holes and cavities were opened vertically in horizontal planes at the earlier stage of Site Design I, they had to be located carefully to fit with the amorphous surface of the Valley as well as the street pattern of the surrounding neighborhood at the final stage. As expected, the third year students approached the physical void in a more complex manner. One of the students treated the urban fabric as 'skin' through a biological analogy and proposed 'pores' that would link the underground spaces with the surface landscape (Figure 6). Another proposal was to cover the Valley with fabric panels following the work of Christo in order to change the way of perceiving the Valley, revealing the void by concealing it (Bourdon, 1972). The project also emphasized various scales superimposed within the area: the size of the fabric panels versus the repetitive neighborhood blocks, the apartment buildings within these blocks versus the new high-rise buildings that stick out in between the panels, the contrast between the solid pattern of the city and the size of the covered void.

The projects focusing on physical voids have scrutinized the void within the practices in urban everyday life. Examining the scales of voids required for human activities as well as social relations and urban functions, these projects created voids of various scales ranging from small niches for individual uses inside the park to the physical definition of the whole Valley as an urban void. In this respect, they questioned the existing patterns of physical voids within the city (streets, lawns, schoolyards and so on) and attempted to incorporate the Valley within these patterns.

\section{Functional voids}

A number of students approached the void as the necessary space for certain functions. Second year students proposed parks with particular functions that would cover the whole surface designated as the park area. One of these proposals was a birdwatching park, in which dense greenery served as functional for the birds to be protected from the traffic and pollution. In addition, the plants literally 'filled' the void and created a dialectical tension between the neighborhood and the park: while the dense greenery cancels the void by filling it, it at the same time marks the park as voided from the urban activities occurring around. Another proposal was almost the inverse of this: a skate park. This time, the park was devoid of soft landscape, and the fluid forms of ramps, pipes, pools and bowls turned the area into a nonvehicular traffic hub for pedestrians, skaters and bicycle riders. Here, the three dimensional void of the Valley was emphasized with the lack of vertical 


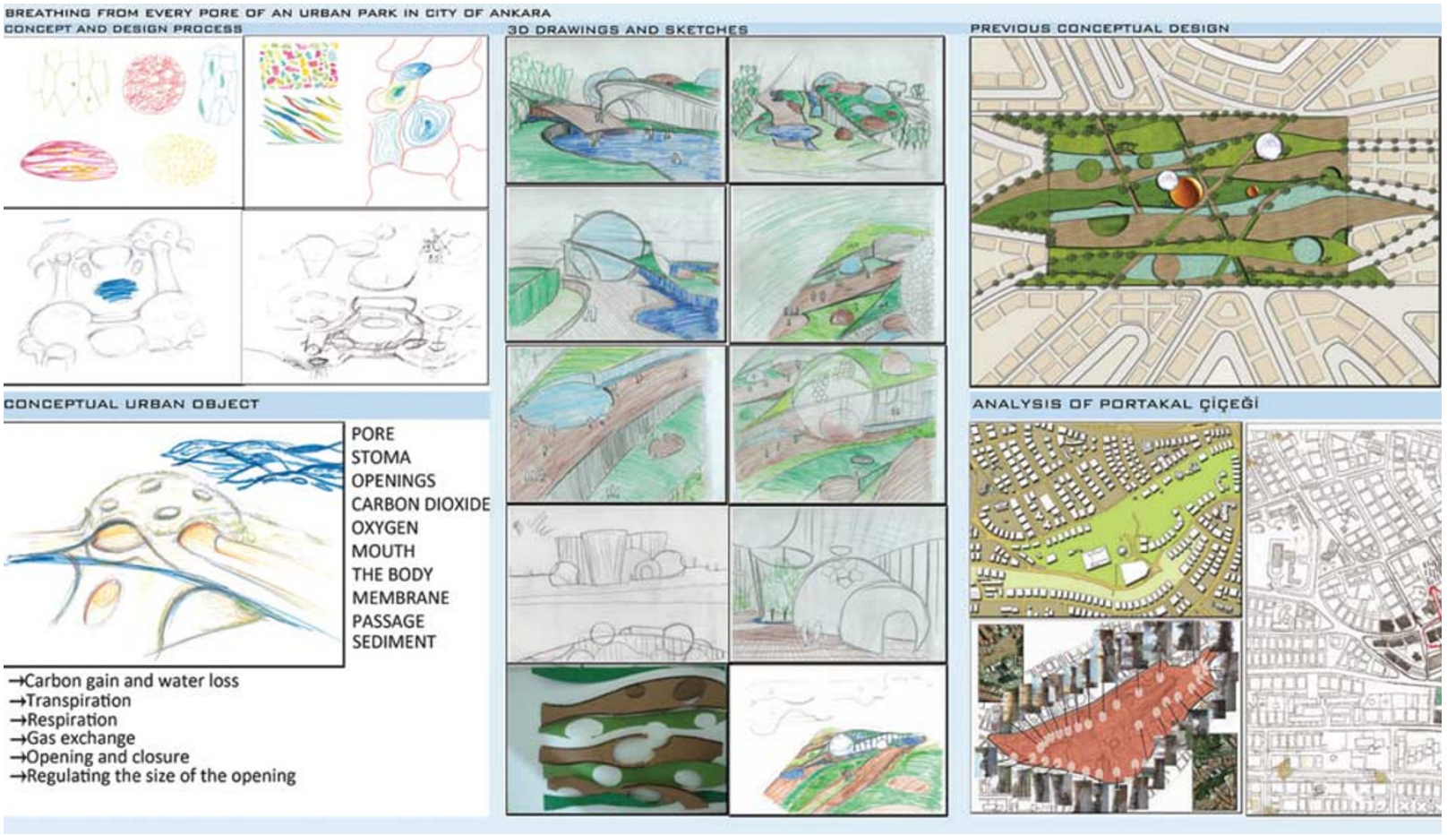

Figure 6: Physical void: 'Pores' - third year project, first phase (Gürkan Güney).

elements and the park was easily perceived as a sunken component of the continuous network of voids in the neighborhood.

Along with the park designs of the second years, there were also third year students who pursued functional voids. Among these, one proposal was interesting in its consistent approach focusing on 'echo'. Analyzing the physical behavior of sound waves and the sources of sound in the actual neighborhood, the student proposed buildings and landscape elements designed as sound barriers to reflect or absorb sound. These elements were carefully positioned to control the level of sound reaching different parts of the area (Figure 7). Another project was a proposal of 'inverse architecture', designing architectural holes working as 'groundscrapers'. Rather than rising up as solid blocks, the spaces were organized around vertical voids, creating a stark contrast with and a critique of - the high-rise blocks located inside the Valley. These projects approached the void not in terms of scale but function. The voids proposed in these projects were integral components of the urban realm not by their morphological qualities but by the functions they undertook. They introduced urban functions derived from the void by accentuating the role of void as the generator of these functions.

\section{Phenomenological voids}

The last group included projects that scrutinized the feelings and emotions triggered by the experience of void. In fact, cities contain such voids, spaces that are outside the urban realm of functionality, which Sola-Morales Rubio, 1995 has defined as terrain vague. Brownfield sites of vacant industrial plants, no-man's lands with no clear identity at city edges and so on provoke sometimes uncanny feelings and inexplicable senses of threat, and sometimes a melancholic belonging triggered by the corrosion of time. In addition, certain geographical forms incite the human senses with an impression of extremity: the heights of a cliff or a canyon triggering vertigo, a crater or an abyss associated with an anxiety of being lost within infinity. Moreover, certain feelings are directly expressed by terms that are variations of void: lack, absence, melancholy and so on. It is not a coincidence that these terms are also frequently used in the field of psychology and especially psychoanalysis. The study of phenomenological voids in urban space is closely related with the bodily experience of the city and its reflections within human psyche (Vidler, 1994; Pile, 1996).

The park designs of the second year students explored such spaces ranging from geographical 


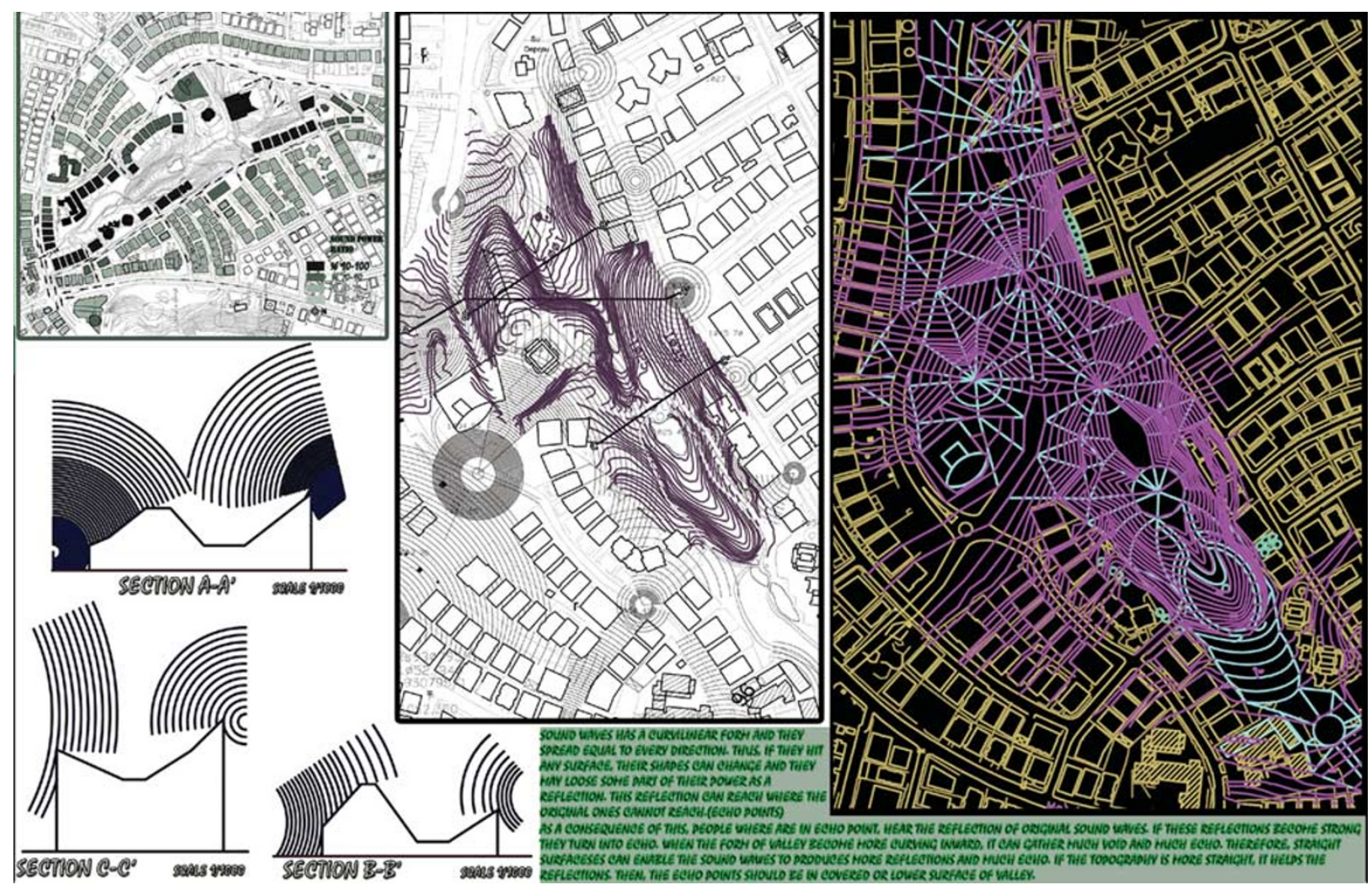

Figure 7: Functional void: 'Echo', third year project (Ahmet Resul Öden).

ones such as craters and canyons to biological ones such as womb. While the geographical voids were imitated in the parks, the womb was realized by an island within a wide lake covering the whole park. In addition, some of the students searched for certain affects of the void, such as isolation and desertedness. In these projects landscape was utilized as a tool to shape human environment by paying particular attention to the spaces created by plants (or their absence). The third year students deployed similar approaches as urban development strategies. One student developed his proposal with reference to the concept of vertigo, where a sunken surface was treated as an intersection point for public and private spheres. The vertigo effect represented the tension between these two spheres and the potential conflicts embodied in the intersection of public and private realms. Pedestrian axes emanating from this intersection area expanded the influence of the project outside the boundaries of the site. Similarly, another student departed from an urban analysis establishing the role of the valleys in the city as green belts and proposed to subvert the treatment of landscape as a tool to domesticate nature in the form of parks.
To this end, the project interpreted void with the concept of lack and introduced a scheme founded on the idea of 'lack of green' (Figure 8). In this proposal, the project site was redesigned with a sense of desolateness accentuating the bits and pieces of landscaping across the conventional urban texture outside the project site.

\section{Assessment: Landscape Urbanism as Critique}

The challenge of having both second and third year students in the urban design studio requires diversifying studio objectives accordingly. Nevertheless, within differentiated design criteria, both of the groups were required to critically engage with the negative aspects of urban renewal processes from within. In this respect, even for the second year students, the urban park was understood not as mere recreation but as a programmatic framework to resist the normative process of urban expansion and the speculative logic of urban renewal.

Since it would be beyond the reach of an undergraduate studio to integrate complex theoretical 


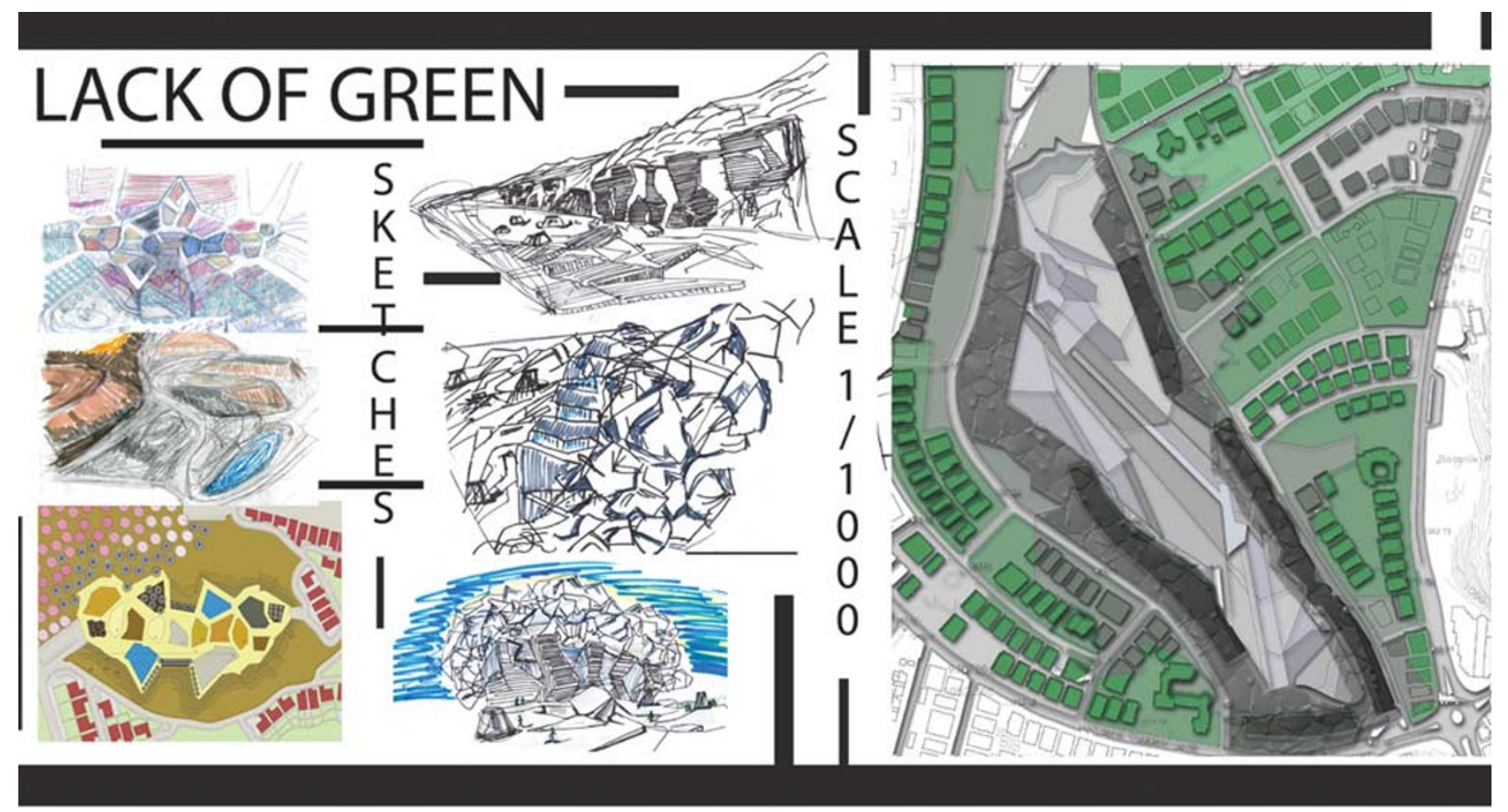

Figure 8: Phenomenological void: 'Lack of Green', third year project (Ece Demircioğlu).

discussions on urbanization and urban design, it was chosen to introduce the problems and issues rather than the theoretical responses to these issues. The problem of urban renewal was not presented as a theoretical subject to be addressed in terms of political economy, sociology and so on, but rather presented to the students through the drift, which served as both a site trip and a social excursion. That is, the pedagogic strategy deployed in the studio did not rely on research but rested on the students' experience in the design process, allowing them to develop immanent critique. In this respect, the objective was to reconfigure the design process in the form of critique by design. Here, while the initial phase of conceptual investigation was an impersonal approach to the urban realm, the drift served as a key component of the design process making the designers identify with the users of space. Provided with multiple points of view regarding the process of urban renewal, the students were guided toward developing their own critical responses in the form of design proposals.

The physical similarity between the two sites allowed for especially the second year students to observe the topographical conditions of construction within a valley. In addition, Dikmen Valley presented them with the very process of transformation that took place in Portakal Çiçeği Valley three decades earlier. Both the physical pattern of the squatter neighborhood and the social life inhabited in the former Valley were elements of the history of the latter one. In this regard, the drift - together with all the unforeseen encounters it embodied - presented the drifters with the historical record of the absence of the relocated squatters in Portakal Çiçeği Valley and the renewal process that took place in the site. In this respect, it is not a coincidence that the Valley, which is currently devoid of life it used to shelter, was treated by the majority of the students as a phenomenological void. In a sense, the interpretation of the Valley as a phenomenological void is a logical outcome of the design process beginning with the sculptures representing the drift as a bodily experience. The students pursuing this approach linked their own experience in the drift with those of the dislocated squatters. An interesting example is a proposal that directly evolved from the sculpture 'the hand of nature' discussed above. The student proposed a linear park with a sunken platform that imitated the cracked form of the sculpture. This artificial Valley ended within the interior of a colossal rock, a form that juxtaposed nature and architecture, and served as the gateway between the park and the surrounding urban environment.

Although the critique by design methodology does not seek to arrive at theoretically valid findings regarding urbanization, it has led to the emergence of overarching points raised by the 
design proposals. A major element of this collective critique was the conscious use of landscape as negation of the conventional urban texture. It was intended to search for alternatives to the dominant mode of urban renewal that replaced low-density squatter neighborhoods with high-rise residential blocks and subordinated green areas to these vertical masses. The prime method of creating such alternatives was the treatment of voids as positive spaces. This choice was also reflected in the survey responses. The students differentiated between 'designing with void' and 'designing a void'; while the former referred to 'voiding' as a positive design approach, the latter was understood as a negative attitude toward 'merely filling' urban voids. Most of the students claimed that their projects prioritized 'designing with void', which for them represented a more 'integrated' approach taking into consideration the urban totality. In this respect, the survey responses often referred to the need for 'open spaces for the city to breath', which was achieved through 'designing with void'. The reversal of the primacy of the structural elements of urban regeneration and the prioritization of horizontal surfaces against building blocks makes it possible to relate the studio work to the debates in landscape urbanism (Mostafavi and Najle, 2003; Waldheim, 2006a).

Landscape urbanism suggests the use of landscape as the major instrument of urban development since it contains the potentials to create 'conditions for radically decentralized urbanization' (Waldheim, 2006b). This approach leads to the production of urban environment through the organization of horizontal surfaces rather than the definition of interiors and exteriors by vertical building blocks. It is necessary to remember that landscape urbanism was a response to first of all the need for the renewal of deindustrialized sites in Northern America and Europe. Proposing to replace architecture with landscape as 'the basic building block of contemporary urbanism', landscape urbanism simultaneously addresses the ecological problems raised by the brownfield sites and the commodification of urban space. It is intended to rehabilitate postindustrial sites and regenerate them as structural elements to improve urban ecology (Corner, 2006). Moreover, landscape urbanism was also strongly influenced by the critiques toward postwar modernist architecture as well as the early cases of urban renewal projects that led to the gentrification of deindustrialized zones in European metropolises (Shannon, 2006). In this respect, it can be argued that landscape urbanism itself is a critique of architecture and urban design as the conventional means of creating urban form.

The works produced in our studio come close to the defining principle of landscape urbanism, utilizing landscape not as a secondary element in an urban environment dominated by vertical architecture but as the major apparatus in creating a horizontal urbanization. Especially the third year projects, which were required to propose strategies of urban development that were derived from the urban park designs of the first stage, came up with suggestions that would expand beyond the project site. These proposals treated the Valley as a landscape generator, transforming its surroundings reversing the relations of solids and voids, that is, buildings and surfaces (Figure 9). New interiors produced in these schemes became subjected to the guidelines of landscape design and emerged as inflations within the horizontal landscape. It is crucial to note that this strategic approach to urban space is not only concerned with producing void(s) as form, but it also uses void as verb. That is, these schemes proposed to change the conventional patterns of social spaces in the city by voiding certain areas. In this respect, the strategy to 'lessen the city' emerged as an approach coherent with landscape urbanism.

The students' responses to the survey question asking them to reflect on their approach to urban renewal in their projects reveal that they deployed strategies prioritizing landscape as an antidote to profit-oriented urban development. Especially the third year students commented on their reaction to urban renewal and expressed that although they did not 'consciously' develop 'an overt critical approach to urban renewal', their proposals displayed an 'ecologically-based rejection' of the current mode of renewal. One student retrospectively defined this as an 'unconsciously produced' alternative 'to the uniform settlements of regeneration projects in progress'. Another one described her approach as one 'critiquing urban renewal and building masses'. Similarly, the student who had proposed 'groundscrapers' defined her intention as developing a socially responsible alternative to 'vertical growth'.

The benefit of conducting the survey 1 year after the studio experience was the prospect of determining its influence on the students' thinking regarding urban renewal, which was not a topic of the studio but one necessarily addressed by the third year students in the following year. One of the student responses illustrates how the studio 

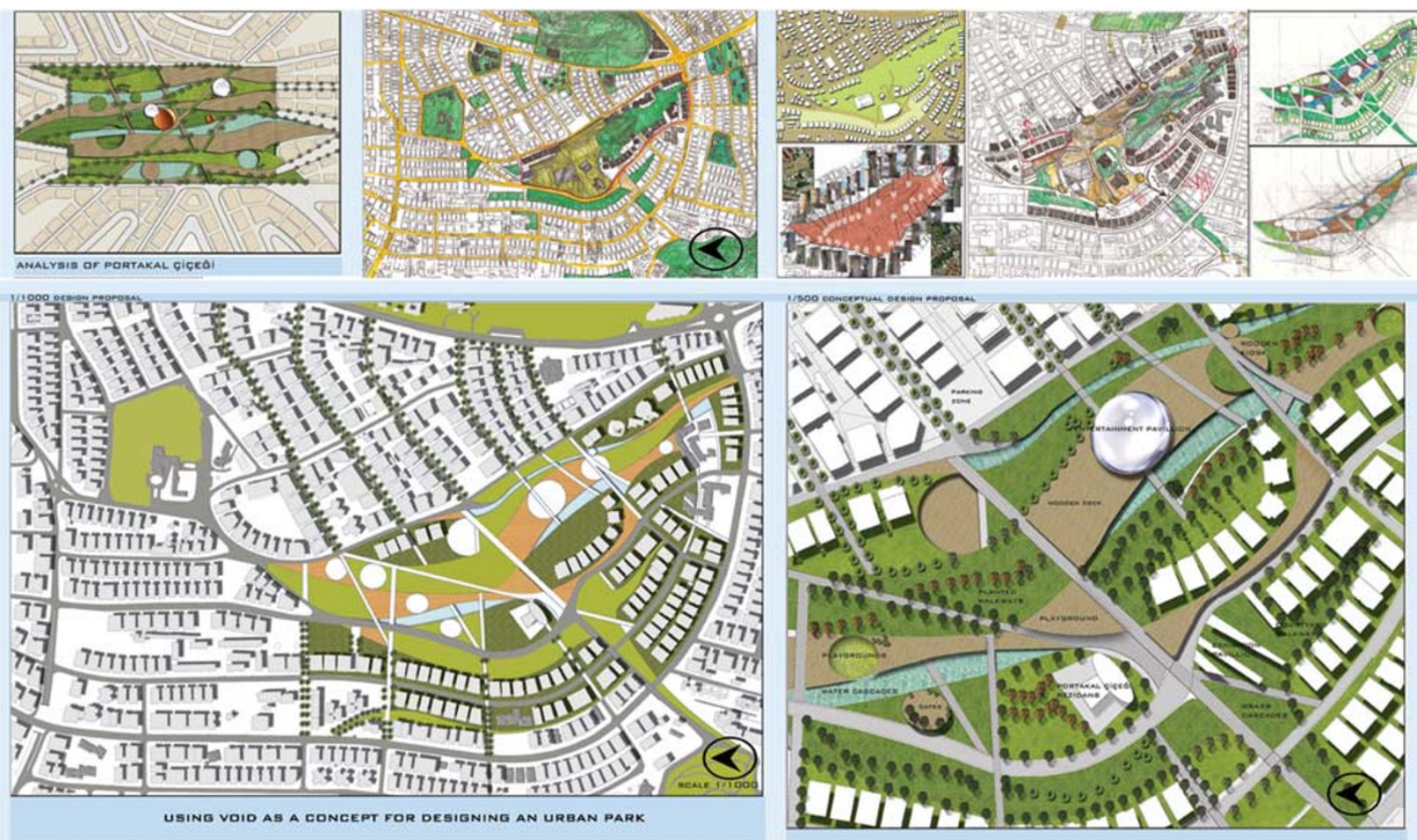

Figure 9: Landscape urbanism: landscape as generator of horizontal urban development, third year project (Gürkan Güney).

affected their critical thinking in the following period of their education: 'Following our drift in Dikmen Valley, we did research on the squatters' struggle and urban renewal was a concept that we frequently came across. This led us to develop a wider perspective and to approach the topic critically'.

\section{Conclusion}

The experimental studio conducted at Bilkent University, Department of Urban Design and Landscape Architecture aimed at developing the methodology of critique by design. This methodology targets the production of urban design projects as the outcomes of a design process in which the students critically engage with the problem they handle. The drift serves as a key in this critical engagement since it transforms the student into the subject of urban renewal. Inhabiting the site of renewal as a walker, the student develops awareness regarding the social and physical environment. The awareness of the (passive) state of the inhabitants of renewal areas radically alters the position of the students as (active) designers. The students' responses to the survey that was conducted a year after the studio work confirm the emergence of such awareness regarding urban renewal.

Moreover, the definition of concepts as the major toolkit to tackle the problem at hand challenges the students to invent new approaches beyond nostalgic proposals resettling the squatters in conventional ways. In other words, the dialectical tension between the impersonal approach of conceptual design and the sensual experience of the drift serves as the initial dynamics of critique by design. In this way, the students translate their critical assessments regarding the design problems into conceptual approaches toward the use of landscape.

The most important outcome of the critique by design methodology is the awareness created in the students, as reflected with the critical edge of their design works. Their responses to the survey demonstrate how the design process became a means for them to develop urban critique. Within the studio work defined for this semester, the application of our methodology with the concept of void and the particular problem of urban park design in Portakal Çiçeği Valley resulted in the production of proposals that are in tune with landscape urbanism, which has endorsed the use of landscape as a model resisting normative processes of urban development. Nevertheless, it is 
possible to adapt this methodology to different design problems by the use of other relevant key concepts.

\section{Acknowledgements}

The authors would like to thank Güven Arif Sargin and Funda Baş Bütüner for their comments on the earlier drafts of the article. We also thank our students Betil Bihter Artan, Ömer Berkay Berberoğlu, Duygu Demir, Meryem Elif Ekşi, Ece Höker, Arzu Hürmüzlü, Tuğçe Hayriye Kalender, Bahanur Hatice Kaynak, Zeynep Özmen, Tuğçe Sıdar, Seda Tokuroğlu, Nurceren Tomruk, Başak Yurtseven, Berkay Arıkan, Elif Cansu Çelikel, Handan Çörekçi, Ece Demircioğlu, Büşra Dok, Havva Gizem Güner, Gürkan Güney, Yeşim Hasbioğlu, Tuğçe Norman, Ahmet Resul Önen and Mehmet Halil Özdemir for their contribution during and after the studio semester.

\section{Notes}

1 For a comparative analysis of the renewal projects in Dikmen and Portakal Çiçeği Valley, see Uzun, 2005.

2 These two formulations came up in the studio discussions although neither was particularly suggested as favorable by the instructors. In the survey, the students were asked how they would evaluate the difference between these two attitudes.

\section{References}

Adorno, T.W. (1983) Negative Dialectics. New York: Seabury Press.

Antonio, R.J. (1981) Immanent critique as the core of critical theory: Its origins and developments in Hegel, Marx and contemporary thought. The British Journal of Sociology 32(3): 330-345.

Arad, M. (2009) Reflecting absence. Places 21(1): 42-51.

Bachelard, G. (1964) The Poetics of Space. Boston, MA: Beacon Press. Batuman, B. (2013) City profile: Ankara. Cities 31(2): 578-590.

Biggs, M. and Büchler, D. (2008) Architectural practice and academic research. Nordic Journal of Architectural Research 20(1): 83-94.

Biggs, M. and Karlsson, H. (eds.) (2011) The Routledge Companion to Research in the Arts. New York and London: Routledge.

Bourdon, D. (1972) Christo. New York: H. N. Abrams.

Brenner, N. and Theodore, N. (2002) Cities and the geographies of actually existing Neoliberalism. In: N. Brenner and N. Theodore (eds.) Spaces of Neoliberalism: Urban Restructuring in North America and Western Europe. Oxford: Blackwell, pp. 2-32.

Bru, E. (2001) Coming from the South. Barcelona, Spain: ACTAR.

Buzan, T. and Buzan, B. (2006) The Mind Map Book: Full Illustrated Edition. London: BBC Books.
Cengizkan, A. (2004) Ankara'nın Ilk Planı: 1924-25 Lörcher Planı [The First plan of Ankara: 1924-25 Lörcher Plan]. Ankara, Turkey: Ankara Enstitüsü Vakfı.

Corner, J. (2006) Terra fluxus. In: C. Waldheim (ed.) The Landscape Urbanism Reader. New York: Princeton Architectural Press, pp. 21-33.

Cuthbert, A. (2006) The Form of Cities: Political Economy and Urban Design. Malden, MA: Blackwell.

Çalışkan, O. (2012) Design thinking in Urbanism: Learning from the designers. URBAN DESIGN International 17(4): $272-296$.

Debord, G. (2009a [1955]) Introduction to a critique of Urban geography. In: T. McDonough (ed.) The Situationists and the City. London and New York: Verso, pp. 59-63.

Debord, G. (2009b [1956]) Theory of the dérive. In: T. McDonough (ed.) The Situationists and the City. London and New York: Verso, pp. 77-85.

Ellin, N. (2006) Integral Urbanism. New York and London: Routledge.

Güzey, Ö. (2009) Urban regeneration and increased competitive power: Ankara in an era of globalization. Cities 26(1): 27-37.

Hackworth, J. (2007) The Neoliberal City: Governance, Ideology and Development in American Urbanism. Ithaca, NY: Cornell University Press.

Hall, P.A. (2010) The Post-Industrial Urban Void/Rethink, Reconnect, Revive. Master's thesis, University of Cincinnati.

Harvey, D. (1989) From managerialism to entrepreneurialism: The transformation in Urban governance in late capitalism. Geographiska Annaler Series B 71(1): 3-18.

Harvey, D. (2003) The Condition of Postmodernity. London: Blackwell.

Inam, A. (2011) From dichotomy to dialectic: Practicing theory in urban design. Journal of Urban Design 16(2): 257-277.

Keleş, R. and Danielson, M.N. (1985) The Politics of Rapid Urbanization; Government and Growth in Modern Turkey. New York: Holmes \& Meier.

Libeskind, D. (1999) Jewish Museum Berlin. Berlin, Germany: G+B Arts International.

Mostafavi, M. and Najle, C. (2003) Landscape Urbanism: A Manual for the Machinic Landscape. London: AA Publications.

Öncü, A. (1988) The politics of the urban land market in Turkey: 1950-1980. International Journal of Urban and Regional Research 12(1): 38-64.

Pile, S. (1996) The Body and the City: Psychoanalysis, Space and Subjectivity. London and New York: Routledge.

Rojas, A. (2009) Urban Voids in Medium Size Chilean Cities. Vague Terrain: Digital Art/Culture/Technology, http:/ / www.vagueterrain.net/journal13/andrea-rojas/01, accessed 12 July 2012.

Sargın, G.A. and Savaş, A. (2012) Dialectical Urbanism: Tactical instruments in Urban design education. Cities 29(6): 358-368.

Savage, S. (2005) Urban design education: Learning for life in practice. URBAN DESIGN International 10(1): 3-10.

Shannon, K. (2006) From theory to resistance: Landscape Urbanism in Europe. In: C. Waldheim (ed.) The Landscape Urbanism Reader. New York: Princeton Architectural Press.

Sola-Morales Rubio, I. (1995) Terrain vague. In: C.C. Davidson (ed.) Anyplace. Cambridge, MA: The MIT Press, pp. 118-123.

Şenyapilı, T. (2004) 'Baraka'dan Gecekonduya: Ankara'da Kentsel Mekanin Dönüşümü 1923-1960 [From shack to gecekondu: Transformation of urban space in Ankara 1923-1960]. Istanbul, Turkey: İletişim. 
Tankut, G. (1994) Bir Başkentin Imarn - Ankara: 1923-1939 [The Construction of a capital - Ankara: 1923-1939]. Istanbul, Turkey: Altın Kitaplar.

Uzun, C.N. (2005) Residential transformation of squatter settlements: Urban redevelopment projects in Ankara. Journal of Housing and the Built Environment 20(2): 183-199.

Ünsal, Ö. and Kuyucu, T. (2010) Challenging the neoliberal urban regime: Regeneration and resistance in Başıüyük and Tarlabaşı. In: D. Göktürk, L. Soysal and İ. Türeli (eds.)
Orienting Istanbul: Cultural Capital of Europe? London: Routledge, pp. 51-70.

Vidler, A. (1994) The Architectural Uncanny: Essays in the Modern Unhomely. Boston, MA: The MIT Press.

Waldheim, C. (ed.) (2006a) The Landscape Urbanism Reader. New York: Princeton Architectural Press.

Waldheim, C. (ed.) (2006b) Landscape as Urbanism. In: The Landscape Urbanism Reader. New York: Princeton Architectural Press, pp. 35-53. 